\title{
Kistimonas asteriae gen. nov., sp. nov., a gammaproteobacterium isolated from Asterias amurensis
}

\author{
Eun Ju Choi, ${ }^{1,2}$ Hak Cheol Kwon, ${ }^{1}$ Young Chang Sohn ${ }^{2}$ \\ and Hyun Ok Yang ${ }^{1}$ \\ ${ }^{1}$ Korea Institute of Science and Technology, Gangneung, Gangwon-do 210-340, Republic of Korea \\ ${ }^{2}$ Division of Applied Marine Biotechnology and Engineering, Faculty of Marine Bioscience and \\ Technology, Gangneung-Wonju National University, Gangneung 210-702, Republic of Korea
}

Correspondence

Hak Cheol Kwon

hkwon@kist.re.kr
Micro-organisms are prolific resources for drug discovery. Since the discovery of actinomycin, more than 13000 bioactive metabolites have been described (Bérdy, 2005). Unfortunately, the number of novel compounds isolated from cultured micro-organisms has been decreasing for more than a decade, while the demand for novel secondary metabolites that might have pharmaceutical benefits has increased in light of the dramatic resistance of tumour cells and pathogenic microbes. One promising method for the discovery of novel compounds is the utilization of bacteria that have not been cultured yet. Many new bacterial taxa have been discovered in marine environments. Some of them could serve as promising genetic resources for the development of new chemical structures. These taxa include the chemically and genetically prolific genera Salinispora and 'Marinispora', from which new structural classes of secondary metabolites have been discovered (Fenical \& Jensen, 2006).

Our first attempt in the course of searching for new microbial taxa was to investigate the marine bacterial diversity associated with the starfish Asterias amurensis. This study resulted in the isolation of 18 culturable marine bacterial strains. NCBI nucleotide BLAST search results

The GenBank/EMBL/DDBJ accession number for the 16S rRNA gene sequence of strain KMD $001^{\top}$ is EU599216. based on partial 16S rRNA gene sequences of the 18 strains revealed that 16 strains had an affiliation with members of the class Gammaproteobacteria. The other two strains were related to the genera Bacillus and Aquimarina. Further analyses of the 16 gammaproteobacteria revealed that the 16S rRNA gene sequence of seven strains shared 99-100\% identity with species of the genus Vibrio, five strains clustered with species of the genus Pseudoalteromonas with sequence similarities of $99-100 \%$, and three strains were related to the genera Halomonas, Shewanella and Colwellia. Phylogenetic analysis of the remaining strain, $\mathrm{KMD} 001^{\mathrm{T}}$, revealed close relationships to the genera Endozoicomonas, Zooshikella and Hahella. The $16 \mathrm{~S}$ rRNA gene sequences of KMD $001^{\mathrm{T}}$ showed $89.7-94.7 \%$ similarity with the aforementioned genera. The low sequence similarity suggested that this bacterium could be distinct from known genera within the class Gammaproteobacteria. In addition, the chemotaxonomic and phenotypic features supported the phylogenetic data, indicating that strain $\mathrm{KMD} 001^{\mathrm{T}}$ belongs to a novel genus and species. In this paper, we propose the description of a new bacterial genus and species, Kistimonas asteriae gen. nov., sp. nov.

Strain $\mathrm{KMD} 001^{\mathrm{T}}$ was isolated from the skin of A. amurensis specimens, which were collected at a depth of $10 \mathrm{~m}$ near the port of Im-Won, located on the Korean East Sea coast (April, 2007). The skin of A. amurensis was 
ground and diluted with sea water $(1: 10)$. The diluted suspension $(100 \mu \mathrm{l})$ was spread onto $\mathrm{A} 1+\mathrm{C}$ agar plates. The $\mathrm{A} 1+\mathrm{C}$ medium contained $10.0 \mathrm{~g}$ starch, $4.0 \mathrm{~g}$ peptone, $2.0 \mathrm{~g}$ yeast extract, $1.0 \mathrm{~g}$ calcium carbonate and $18.0 \mathrm{~g}$ agar per litre filtered seawater. Plates were incubated for 2 weeks at $25{ }^{\circ} \mathrm{C}$. Colonies were then isolated and purified on $\mathrm{A} 1+\mathrm{C}$ agar. The pure bacterial strains were subsequently cultured in liquid $\mathrm{A} 1+\mathrm{C}$ medium $(25 \mathrm{ml})$ for 7 days at $25{ }^{\circ} \mathrm{C}$. The stocks of all cultures were stored at $-80{ }^{\circ} \mathrm{C}$ in culture medium containing $15 \%$ glycerol until further use.

Cells that were cultured at $25{ }^{\circ} \mathrm{C}$ for 7 days on $\mathrm{A} 1+\mathrm{C}$ agar and marine agar plates were used for morphological studies. The ability of strain KMD $001^{\mathrm{T}}$ to grow at different temperatures was examined using cultures on $\mathrm{A} 1+\mathrm{C}$ agar and marine agar plates at $4,10,15,20,25,30$, 37 and $42{ }^{\circ} \mathrm{C}$. In addition, the ability to grow on different media was tested at $25{ }^{\circ} \mathrm{C}$ with the following media investigated: nutrient agar (Difco), marine agar (Difco), Tryptone Soy Broth Agar (TSA; Merck), starch agar (Difco) and xylan agar (Difco). Requirement for and tolerance of $\mathrm{NaCl}$ were examined in a medium that contained $\mathrm{NaCl}$ at different concentrations $(0-15 \%$, w/v, with intervals of $1 \%)$. Growth at different $\mathrm{pH}$ was tested on $\mathrm{A} 1+\mathrm{C}$ agar plates for which the $\mathrm{pH}$ was adjusted to 4 10 with intervals of $1 \mathrm{pH}$ unit. Gram staining of KMD $001^{\mathrm{T}}$ was performed according to the method described by Süßmuth et al. (1987). The ability of the strain to produce a fluorescent pigment was tested using King B medium (King et al., 1954). Utilization of carbon sources was investigated by using the API $50 \mathrm{CH}$ tests (bioMérieux) according to the manufacturer's recommendations. In addition, API 20E, API 20NE and API ZYM kits (bioMérieux) using culture media containing $0.85 \%$ $\mathrm{NaCl}$ were used to determine additional biochemical properties.

Fatty acid methyl esters were extracted and prepared according to the standard protocol of the MIDI/Hewlett Packard Microbial Identification System (Sasser, 1990). The DNA G $+\mathrm{C}$ content was determined by HPLC analysis as described by Martin et al. (1997). Isoprenoid quinones were extracted according to the method described by Bligh \& Dyer (1959) and separated by HPLC, as described by Collins \& Jones (1981). Cells that were cultured at $25{ }^{\circ} \mathrm{C}$ for 7 days in $\mathrm{A} 1+\mathrm{C}$ liquid medium were used for morphology observation using a scanning electron microscope (S-3500N; Hitachi).

The chromosomal DNA of strain KMD $001^{\mathrm{T}}$ was isolated using the G-spin genomic DNA extraction kit (iNtRON Biotechnology). The 16S rRNA gene was amplified by PCR using the universal primers $27 \mathrm{f}$ and $1492 \mathrm{r}$. These primers correspond to position 27 in the forward direction and 1492 in the reverse direction of the 16S rRNA gene of the Escherichia coli genome (Brosius et al., 1978). Analysis of the DNA sequence was carried out by using the ABI prism BigDye terminator cycle sequencing Ready reaction kit v.3.1 (Applied Biosystems). The PCR product was purified using the Montage dye removal kit (Millipore) according to the procedure described by the manufacturer. 16S rRNA gene sequences were determined by using a capillary DNA sequencer (Perkin-Elmer model ABI 3730XL; Applied Biosystems). Similarity of the 16S rRNA gene sequence (1506 bp) of strain KMD $001^{\mathrm{T}}$ to previously known sequences was determined by performing BLAST searches in the GenBank/EMBL/DDBJ database (Altschul et al., 1990). Multiple sequence alignment of representative sequences was performed using the CLUSTAL $\mathrm{W}$ program (version 1.8; Thompson et al., 1994). Neighbour-joining analysis (Kimura, 1980) and a bootstrap analysis were performed using 1000 resampled datasets in order to determine the robustness of each topology. A phylogenetic tree was reconstructed by using the program MEGA4 (Tamura et al., 2007).

Strain KMD $001^{\mathrm{T}}$ is a Gram-stain-negative, aerobic, motile and short rod-shaped bacterium. It formed light-yellowishpigmented colonies on $\mathrm{A} 1+\mathrm{C}$ medium, nutrient agar, marine agar and TSA medium at $25{ }^{\circ} \mathrm{C}$. Growth was also observed on seawater base starch agar (17 g starch and $18 \mathrm{~g}$ agar per litre filtered seawater) and xylan agar medium (17 $\mathrm{g}$ xylan and $18 \mathrm{~g}$ agar per litre filtered seawater) at $25^{\circ} \mathrm{C}$. Growth of KMD $001^{\mathrm{T}}$ was observed at pH $5-10$ and at temperatures between 15 and $30^{\circ} \mathrm{C}$, with an optimal temperature of $25^{\circ} \mathrm{C}$. The strain did not grow at $4,10,37$ or $42{ }^{\circ} \mathrm{C}$. In addition, no growth was observed in $\mathrm{A} 1+\mathrm{C}$ medium containing $0 \%$ or $11-15 \% \mathrm{NaCl}$. Strain KMD $001^{\mathrm{T}}$ did not produce a fluorescent pigment when cultured on King B medium. Detailed phenotypic data are shown in the species description and in Table 1.

The cellular fatty acid profiles of strain KMD $001^{\mathrm{T}}$, Endozoicomonas elysicola and Zooshikella ganghwensis are shown in Table 2. The predominant fatty acids of strain KMD $001^{\mathrm{T}}$ are iso- $\mathrm{C}_{15: 0}$, anteiso- $\mathrm{C}_{15: 0}$ and iso- $\mathrm{C}_{14: 0}$. The DNA G + C content of strain KMD $001^{\mathrm{T}}$ is $47.6 \mathrm{~mol} \%$. Q-9 was detected as the predominant isoprenoid quinone. Scanning electron microscope observations of KMD $001^{\mathrm{T}}$ revealed short rod-shaped bacterial cells, $1.0-1.6 \mu \mathrm{m}$ in length and $0.3-0.5 \mu \mathrm{m}$ in diameter (Fig. 1).

The 16S rRNA gene sequence (1506 bp) of strain KMD $001^{\mathrm{T}}$ is most closely related to E. elysicola MKT $110^{\mathrm{T}}$ $(94.6 \%)$ and Z. ganghwensis JC2044 ${ }^{\mathrm{T}}(91.8 \%)$ (Fig. 2).

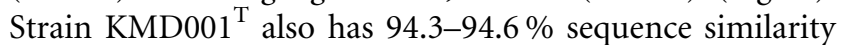
to undescribed sponge isolates related to E. elysicola. A previously published study suggested that strain E. elysicola MKT $110^{\mathrm{T}}$ formed a sister clade with the genus Zooshikella, which belongs to the family Hahellaceae in the order Oceanospirillales (Kurahashi \& Yokota, 2007). Strain KMD $001^{\mathrm{T}}$ could also be considered another sister clade of Zooshikella; however, $\mathrm{KMD} 001^{\mathrm{T}}$ is also closely related to several other genera, as shown in Fig. 2, such as Oceanospirillum (90.8-91.1\% similarity) (Satomi et al., 1998), Marinobacter (89.5-91.1\% similarity) (Anzai et al., 2000; Martín et al., 2003; Yoon et al., 2003b), Balneatrix 
Table 1. Differential characteristics of strain $\mathrm{KMD} 001^{\top}$ and its closest phylogenetic neighbours

Strains: 1, KMD $001^{\mathrm{T}}$; 2, Endozoicomonas elysicola MKT110 (data from Kurahashi \& Yokota, 2007); 3, Zooshikella ganghwensis $\mathrm{JC}_{2044^{\mathrm{T}}}$ (Yi et al., 2003). +, Positive reaction or growth; -, negative reaction or no growth; NR, not recorded; NPG, $p$-nitrophenyl- $\beta$-D-galactopyranoside and $o$-nitrophenyl- $\beta$-Dgalactopyranoside.

\begin{tabular}{|c|c|c|c|}
\hline Characteristic & 1 & 2 & 3 \\
\hline Colour of colonies & Light yellow & Beige & Yellowish-red or red \\
\hline Cell size $(\mu \mathrm{m})$ & $0.3-0.5 \times 1.0-1.6$ & $0.4-0.6 \times 1.8-2.2$ & $0.7-0.9 \times 1.5-2.5$ \\
\hline Growth at $37{ }^{\circ} \mathrm{C}$ & - & - & + \\
\hline Nitrate reduction to nitrite & - & + & + \\
\hline \multicolumn{4}{|l|}{ Hydrolysis of: } \\
\hline Aesculin & - & + & - \\
\hline Gelatin & + & - & + \\
\hline Starch & + & NR & + \\
\hline Casein & - & NR & + \\
\hline NPG & + & - & - \\
\hline \multicolumn{4}{|l|}{ Utilization of: } \\
\hline Arginine & - & - & + \\
\hline Cellobiose & + & NR & - \\
\hline Ornithine & - & - & + \\
\hline Fructose & + & - & + \\
\hline Glycerol & + & NR & - \\
\hline Inositol & + & NR & - \\
\hline Lactose & + & - & - \\
\hline Mannitol & + & - & - \\
\hline Melibiose & + & - & NR \\
\hline Ribose & + & - & + \\
\hline Sucrose & + & - & - \\
\hline $\begin{array}{l}\text { DNA G + C content } \\
(\mathrm{mol} \%)\end{array}$ & 47.6 & 50.4 & $40-42$ \\
\hline \multirow[t]{3}{*}{ Major fatty acids } & iso- $\mathrm{C}_{15: 0}$ & $\mathrm{C}_{14: 0} 3-\mathrm{OH}$ & $\mathrm{C}_{16: 0}$ \\
\hline & anteiso- $\mathrm{C}_{15: 0}$ & $\mathrm{C}_{10: 0} 3-\mathrm{OH}$ & $\mathrm{C}_{16: 1} \omega 7 c$ \\
\hline & iso- $\mathrm{C}_{14: 0}$ & $\mathrm{C}_{12: 0} 3-\mathrm{OH}$ & $\mathrm{C}_{18: 1} \omega 7 c$ \\
\hline
\end{tabular}

(90.3\% similarity) (Dauga et al., 1993), Oleiphilus $(90.2 \%$ similarity) (Golyshin et al., 2002), Alcanivorax (90.1\% similarity), Microbulbifer (91.1-92.0\% similarity) (Yoon et al., 2003, 2004) and Pseudomonas (89.5-91.5\% similarity) (Anzai et al., 1997; Dabboussi et al., 1999; Peix et al., 2005; Ramette et al., 2001; Sikorski et al., 2001; Tvrzová et al., 2006; Verhille et al., 1999). In addition, the 16S rRNA gene sequence of strain $\mathrm{KMD} 001^{\mathrm{T}}$ showed similarities of $89.7 \%$ and $89.4 \%$ with Hahella ganghwensis and Hahella chejuensis, respectively (Baik et al., 2005; Lee et al., 2001). Strain KMD $001^{\mathrm{T}}$ also showed similarity (87.0-90.3\%) with various species belonging to the order Oceanospirillales.

According to our results, strain $\mathrm{KMD} 001^{\mathrm{T}}$ is clearly distinguishable from its phylogenetic neighbours, E. elysicola and $Z$. gangwhensis, by its fatty acid profile, the ability to reduce nitrate, $\beta$-galactosidase activity, and the utilization of lactose and mannitol (Tables 1 and 2) (Kurahashi \& Yokota, 2007; Yi et al., 2003). In the case of fatty acid composition, 3-hydroxy fatty acids and a
$\mathrm{C}_{16: 1} \omega 7 c$ unsaturated fatty acid were detected in E. elysicola and Z. ganghwensis, but not in $\mathrm{KMD} 001^{\mathrm{T}}$. However, iso- and anteiso-fatty acids were the dominant forms in $\mathrm{KMD} 001^{\mathrm{T}}$. The differences between KMD $001^{\mathrm{T}}$ and the species shown in Fig. 2 are also clearly supported by fatty acid composition, DNA G $+\mathrm{C}$ content and the major isoprenoid quinone, as well as the very low $16 \mathrm{~S}$ rRNA gene sequence similarity. In particular, species of the genus Oceanospirillum contain Q-8 as the major isoprenoid quinone (Satomi et al., 2002). Species of the genera Marinobacter, Microbulbifer, Litoricola, Oleiphilus and Alcanivorax have DNA $\mathrm{G}+\mathrm{C}$ contents of over $52 \mathrm{~mol} \%$ and contain $\mathrm{C}_{16: 1} \omega 7 c$ or $\mathrm{C}_{18: 1} \omega 7 c$ unsaturated fatty acid (Yoon et al., 2003a,b, 2004; Kim et al., 2007; Golyshin et al., 2002; Liu \& Shao, 2005). No iso- or anteiso-fatty acids were detected in species of the genera Pseudomonas and Hahella (Peix et al., 2005; Baik et al., 2005). On the basis of the phenotypic, chemotaxonomic and genotypic features, strain KMD $001^{\mathrm{T}}$ should be assigned to a novel genus in the class 
Table 2. Cellular fatty acid profiles of strain $\mathrm{KMD} 001^{\top}$ and its closest phylogenetic neighbours

Strains: 1, KMD $001^{\mathrm{T}}$; 2, Endozoicomonas elysicola MKT110 ${ }^{\mathrm{T}}$ (data from Kurahashi \& Yokota, 2007); 3, Zooshikella ganghwensis JC2044 ${ }^{\mathrm{T}}$ (data from Yi et al., 2003).

\begin{tabular}{|lccc|}
\hline Fatty acid (\%) & $\mathbf{1}$ & $\mathbf{2}$ & $\mathbf{3}$ \\
\hline iso- $_{14: 0}$ & 11.96 & - & - \\
iso- $\mathrm{C}_{15: 0}$ & 21.31 & - & - \\
iso- $_{16: 0}$ & 6.39 & - & - \\
iso- $_{17: 0}$ & 1.45 & - & - \\
iso- $\mathrm{C}_{18: 0}$ & 0.27 & - & - \\
iso- $\mathrm{C}_{17: 1} \omega 10 c$ & 3.85 & - & - \\
anteiso-C $15: 0$ & 31.36 & - & - \\
anteiso-C $17: 0$ & 3.5 & - & - \\
$\mathrm{C}_{10: 0} 3-\mathrm{OH}$ & - & 3.1 & 2.1 \\
$\mathrm{C}_{12: 0} 3-\mathrm{OH}$ & - & 2.8 & 5.1 \\
$\mathrm{C}_{12: 1} 3-\mathrm{OH}$ & - & - & $<0.5$ \\
$\mathrm{C}_{14: 0} 3-\mathrm{OH}$ & - & 4.1 & - \\
$\mathrm{C}_{10: 0}$ & - & 1 & 2.6 \\
$\mathrm{C}_{12: 0}$ & - & 6.5 & $<0.5$ \\
$\mathrm{C}_{14: 0}$ & 0.72 & 9.3 & 6.0 \\
$\mathrm{C}_{15: 0}$ & - & 0.7 & - \\
$\mathrm{C}_{16: 0}$ & 1.06 & 18.9 & 31.9 \\
$\mathrm{C}_{18: 0}$ & - & 0.8 & 0.7 \\
$\mathrm{C}_{16: 1} \omega 7 c$ & - & 54.5 & 37.1 \\
$\mathrm{C}_{16: 1} \omega 7 c$ alcohol & 7.01 & - & - \\
$\mathrm{C}_{16: 1} \omega 11 c$ & 4.49 & - & - \\
$\mathrm{C}_{18: 1} \omega 7 c$ & - & 5.5 & 14.5 \\
$\mathrm{C}_{18: 1} \omega 9 c$ & 0.36 & - & - \\
$\mathrm{Summed}$ feature $4 *$ & 6.26 & - & - \\
& & & \\
\hline
\end{tabular}

${ }^{*}$ Summed features are groups of two or three fatty acids that cannot be separated by GLC using the MIDI system. Summed feature 4 comprises iso- $\mathrm{C}_{17: 1} \mathrm{I}$ and/or anteiso- $\mathrm{C}_{17: 1} \mathrm{~B}$.

Gammaproteobacteria. We propose that strain KMD $001^{\mathrm{T}}$ be classified as the novel genus and species Kistimonas asteriae gen. nov., sp. nov.

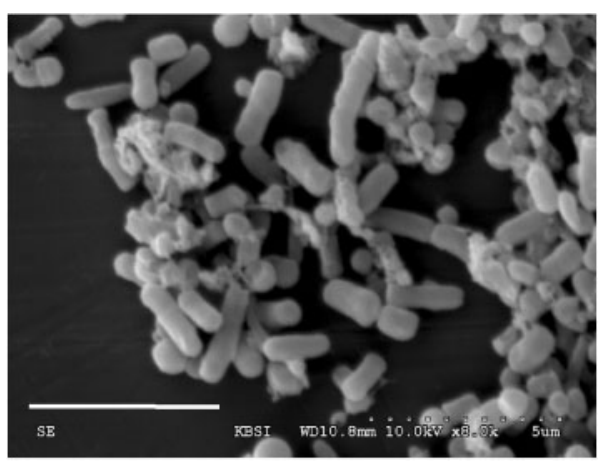

Fig. 1. Scanning electron microscope image showing short rods of strain $\mathrm{KMD} 001^{\top}$. The organism was grown on $\mathrm{A} 1+\mathrm{C}$ medium at $25^{\circ} \mathrm{C}, 200$ r.p.m. for 7 days. Bar, $5 \mu \mathrm{m}$.

\section{Description of Kistimonas gen. nov.}

Kistimonas [Kis.ti.mo'nas. N.L. n. kistum acronym of the Korea Institute of Science and Technology (KIST); L. fem. n. monas a unit, monad; N.L. fem. n. Kistimonas Kist monad].

Do not produce a fluorescent pigment on King B medium. Isoprenoid quinone Q-9 is detected. The predominant fatty acids are iso- $\mathrm{C}_{15: 0}$, anteiso- $\mathrm{C}_{15: 0}$ and iso- $\mathrm{C}_{14: 0}$. The DNA $\mathrm{G}+\mathrm{C}$ content of the type strain of the type species is $47.6 \mathrm{~mol} \%$. The genus Kistimonas is a member of the class Gammaproteobacteria. The type species is Kistimonas asteriae.

\section{Description of Kistimonas asteriae sp. nov.}

Kistimonas asteriae (as.te'ri.ae. N.L. gen. n. asteriae of Asterias amurensis, a starfish).

Cells are Gram-stain-negative, aerobic, motile and rodshaped. Light-yellow-pigmented colonies are formed on $\mathrm{A} 1+\mathrm{C}$ medium, nutrient agar, marine agar and TSA medium. Grows between 15 and $30{ }^{\circ} \mathrm{C}$, with an optimal temperature of $25^{\circ} \mathrm{C}$. Does not grow at $4,10,37$ or $42{ }^{\circ} \mathrm{C}$. No growth observed in $\mathrm{A} 1+\mathrm{C}$ medium prepared with deionized water without $\mathrm{NaCl}$. No colonies detected when medium contains $11-15 \% \mathrm{NaCl}$. Growth is reduced by $\mathrm{NaCl}$ at concentrations higher than $9 \%(\mathrm{w} / \mathrm{v})$. Grows at $\mathrm{pH}$ 5-10 but not at $\mathrm{pH}$ 4. Can utilize the following carbon sources in the API 50CH test: glycerol, ribose, galactose, D-glucose, D-fructose, inositol, mannitol, methyl- $\alpha$-D-glucopyranoside, amygdalin, arbutin, aesculin, salicin, cellobiose, maltose, lactose, melibiose, sucrose, trehalose, melezitose, raffinose, starch, glycogen, $\beta$-gentiobiose, turanose, D-tagatose, L-arabitol and potassium 5-ketogluconate. Can also use gelatin and xylan as a carbon source, but not casein or alginate. Shows $\beta$ galactosidase activity as determined by a nitrophenyl- $\beta$-Dgalactopyranoside reaction in API 20E and API 20NE tests (Table 1). Does not produce $\mathrm{H}_{2} \mathrm{~S}$, indole or acetoin. Positive for the oxidation of glucose, mannitol, sucrose and melibiose, and the assimilation of glucose, mannitol, $\mathrm{N}$-acetylglucosamine, maltose, gluconate and malate in API 20E and API 20NE tests. Shows cytochrome oxidase activity. API ZYM tests using naphthyl-substrates indicate positive results for the activities of alkaline phosphatase, esterase (C4) and esterase lipase (C8). However, test results are negative for lipase (C14), leucine arylamidase, valine arylamidase, cystine arylamidase, trypsin, $\alpha$-chymotrypsin, acid phosphatase, naphthol-AS-BI-phosphohydrolase, $\alpha$-galactosidase, $\beta$ galactosidase, $\beta$-glucuronidase, $\alpha$-glucosidase, $\beta$-glucosidase, $N$-acetyl- $\beta$-glucosaminidase, $\alpha$-mannosidase and $\alpha$-fucosidase.

The type strain KMD 001 ${ }^{\mathrm{T}}\left(\mathrm{KCCM} 90076^{\mathrm{T}}=\mathrm{JCM} 15607^{\mathrm{T}}\right)$ was isolated from the skin of Asterias amurensis collected at the Im-Won port in Samcheok, East Sea in Korea. 


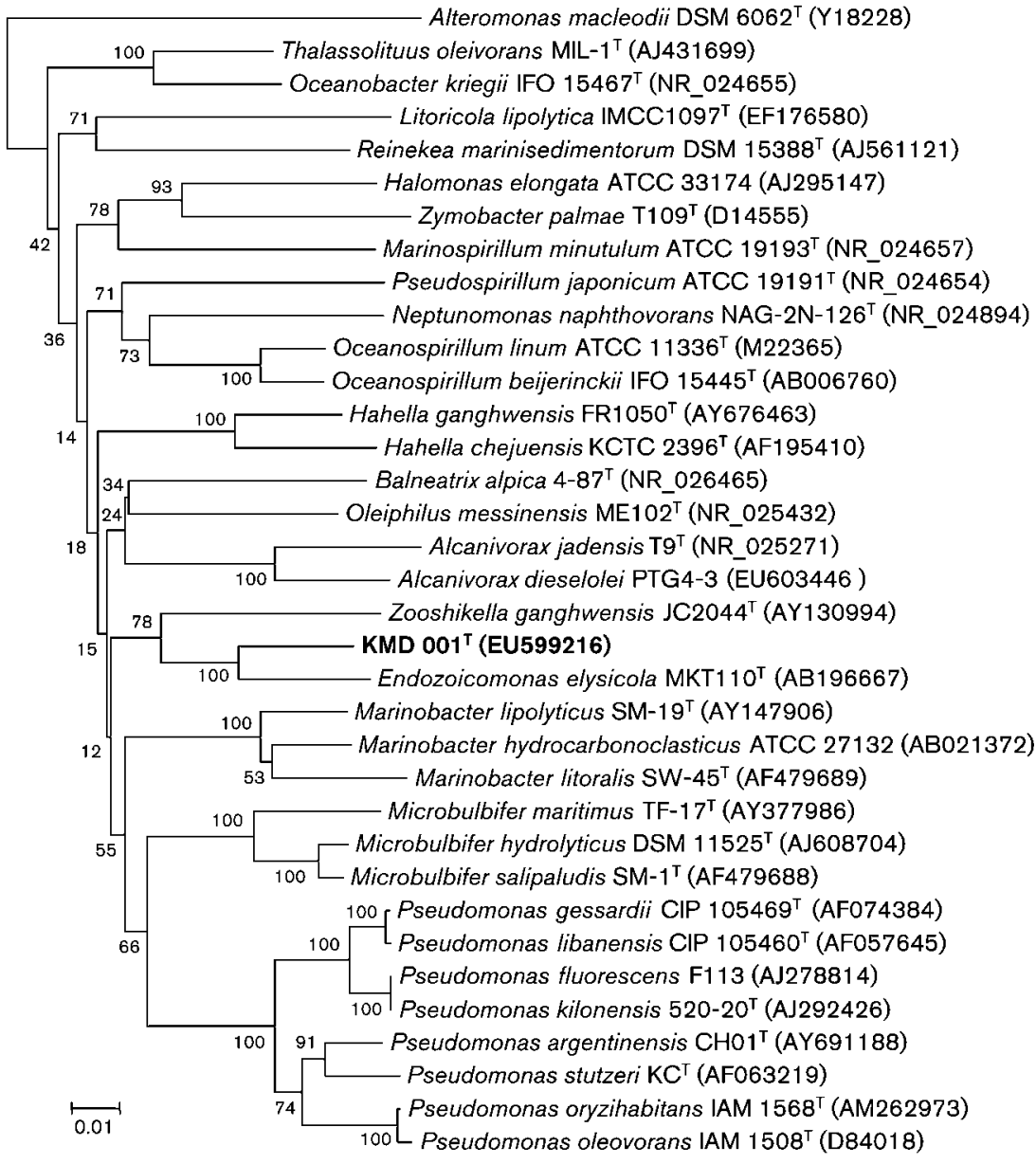

Fig. 2. Phylogenetic tree based on the $16 \mathrm{~S}$ rRNA gene sequences of strain $\mathrm{KMD} 001^{\top}$ and members of related genera within the class Gammaproteobacteria. Bar, 0.01 substitutions per nucleotide position. Bootstrap confidence values (\%) obtained with 1000 resamplings are given at the branch-points.

\section{Acknowledgements}

E. J. C. was a recipient of a graduate fellowship partially provided by the Brain Korea (BK21) program sponsored by the Ministry of Education and Human Resources Development, South Korea. This study was supported by the Korea Institute of Science and Technology institutional program, grant nos 2Z03100 and 2Z03270, Republic of Korea. We would like to thank D. J. Lee of 21C Submarine R\&D for collecting starfish specimens.

\section{References}

Altschul, S. F., Gish, W., Miller, W., Myers, E. W. \& Lipman, D. J. (1990). Basic local alignment search tool. J Mol Biol 215, 403-410.

Anzai, Y., Kudo, Y. \& Oyaizu, H. (1997). The phylogeny of the genera Chryseomonas, Flavimonas, and Pseudomonas supports synonymy of these three genera. Int J Syst Bacteriol 47, 249-251.

Anzai, Y., Kim, H., Park, J. Y., Wakabayashi, H. \& Oyaizu, H. (2000). Phylogenetic affiliation of the pseudomonads based on 16S rRNA sequence. Int J Syst Evol Microbiol 50, 1563-1589.

Baik, K. S., Seong, C. N., Kim, E. M., Yi, H., Bae, K. S. \& Chun, J. (2005). Hahella ganghwensis sp. nov., isolated from tidal flat sediment. Int J Syst Evol Microbiol 55, 681-684.

Bérdy, J. (2005). Bioactive microbial metabolites: a personal view. $J$ Antibiot 58, 1-26.

Bligh, E. G. \& Dyer, W. J. (1959). A rapid method of total lipid extraction and purification. Can J Biochem Physiol 37, 911-917.
Brosius, J., Palmer, M. L., Kennedy, P. J. \& Noller, H. F. (1978). Complete nucleotide sequence of a $16 \mathrm{~S}$ ribosomal RNA gene from Escherichia coli. Proc Natl Acad Sci U S A 75, 4801-4805.

Collins, M. D. \& Jones, D. J. (1981). A note on the separation of natural mixtures of bacterial ubiquinones using reverse-phase partition thin-layer chromatography and high performance liquid chromatography. J Appl Bacteriol 51, 129-134.

Dabboussi, F., Hamze, M., Elomari, M., Verhille, S., Baida, N., Izard, D. \& Leclerc, H. (1999). Pseudomonas libanensis sp. nov., a new species isolated from Lebanese spring waters. Int J Syst Evol Microbiol 49, 1091-1101.

Dauga, C., Gillis, M., Vandamme, P., Ageron, E., Grimont, F., Kersters, K., de Mahenge, C., Peloux, Y. \& Grimont, P. A. (1993). Balneatrix alpica gen. nov., sp. nov., a bacterium associated with pneumonia and meningitis in a spa therapy center. Res Microbiol 144, 35-46.

Fenical, W. \& Jensen, J. R. (2006). Developing a new resource for drug discovery: marine actinomycete bacteria. Nat Chem Biol 2, 666-673.

Golyshin, P. N., Chernikova, T. N., Abraham, W. R., Lünsdorf, H., Timmis, K. N. \& Yakimov, M. M. (2002). Oleiphilaceae fam. nov., to include Oleiphilus messinensis gen. nov., sp. nov., a novel marine bacterium that obligately utilizes hydrocarbons. Int J Syst Evol Microbiol 52, 901-911.

Kim, H., Choo, Y. J. \& Cho, J. C. (2007). Litoricolaceae fam. nov., to include Litoricola lipolytica gen. nov., sp. nov., a marine bacterium belonging to the order Oceanospirillales. Int J Syst Evol Microbiol 57, $1793-1798$. 
Kimura, M. (1980). A simple method for estimating evolutionary rates of base substitutions through comparative studies of nucleotide sequences. J Mol Evol 16, 111-120.

King, E. O., Ward, M. K. \& Raney, D. E. (1954). Two simple media for the demonstration of pyocyanin and fluorescin. J Lab Clin Med 44, 301-307.

Kurahashi, M. \& Yokota, A. (2007). Endozoicomonas elysicola gen. nov., sp. nov., a $\gamma$-proteobacterium isolated from the sea slug Elysia ornata. Syst Appl Microbiol 30, 202-206.

Lee, H. K., Chun, J., Moon, E. Y., Ko, S. H., Lee, D. S., Lee, H. S. \& Bae, K. S. (2001). Hahella chejuensis gen. nov., sp. nov., an extracellularpolysaccharide-producing marine bacterium. Int J Syst Evol Microbiol 51, 661-666.

Liu, C. \& Shao, Z. (2005). Alcanivorax dieselolei sp. nov., a novel alkane-degrading bacterium isolated from sea water and deep-sea sediment. Int J Syst Evol Microbiol 55, 1181-1186.

Martin, K., Schumann, P., Rainey, F. A., Schuetze, B. \& Groth, I. (1997). Janibacter limosus gen. nov., sp. nov., a new actinomycete with mesodiaminopimelic acid in the cell wall. Int J Syst Bacteriol 47, 529-534.

Martín, S., Márquez, M. C., Sánchez-Porro, C., Mellado, E., Arahal, D. R. \& Ventosa, A. (2003). Marinobacter lipolyticus sp. nov., a novel moderate halophile with lipolytic activity. Int J Syst Evol Microbiol 53, 1383-1387.

Peix, A., Berge, O., Rivas, R., Abril, A. \& Velázquez, E. (2005). Pseudomonas argentinensis sp. nov., a novel yellow pigmentproducing bacterial species, isolated from rhizospheric soil in Córdoba, Argentina. Int J Syst Evol Microbiol 55, 1107-1112.

Ramette, A., Moënne-Loccoz, Y. \& Défago, G. (2001). Polymorphism of the polyketide synthase gene phID in biocontrol fluorescent pseudomonads producing 2,4-diacetylphloroglucinol and comparison of PhID with plant polyketide synthases. Mol Plant Microbe Interact 14, 639-652.

Sasser, M. (1990). Identification of bacteria by gas chromatography of cellular fatty acids, MIDI Technical Note 101. Newark, DE: MIDI Inc.

Satomi, M., Kimura, B., Hayashi, M., Shouzen, Y., Okuzumi, M. \& Fujii, T. (1998). Marinospirillum gen. nov., with descriptions of Marinospirillum megaterium sp. nov., isolated from kusaya gravy, and transfer of Oceanospirillum minutulum to Marinospirillum minutulum comb. nov. Int J Syst Bacteriol 48, 1341-1348.

Satomi, M., Kimura, B., Hamada, T., Harayama, S. \& Fujii, T. (2002). Phylogenetic study of the genus Oceanospirillum based on 16S rRNA and $g y r B$ genes: emended description of the genus Oceanospirillum, description of Pseudospirillum gen. nov., Oceanobacter gen. nov. and Terasakiella gen. nov. and transfer of Oceanospirillum jannaschii and Pseudomonas stanieri to Marinobacterium as Marinobacterium jannaschii comb. nov. and Marinobacterium stanieri comb. nov. Int J Syst Evol Microbiol 52, 739-747.

Sikorski, J., Jahr, H. \& Wackernagel, W. (2001). The structure of a local population of phytopathogenic Pseudomonas brassicacearum from agricultural soil indicates development under purifying selection pressure. Environ Microbiol 3, 176-186.

Süßmuth, R., Eberspächer, J., Haag, R. \& Springer, W. (1987). Biochemisch-mikrobiologisches Praktikum. Stuttgart \& New York: Thieme (in German).

Tamura, K., Dudley, J., Nei, M. \& Kumar, S. (2007). MEGA4: molecular evolutionary genetics analysis (MEGA) software version 4.0. Mol Biol Evol 24, 1596-1599.

Thompson, J. D., Higgins, D. G. \& Gibson, T. J. (1994). CLUSTAL W: improving the sensitivity of progressive multiple sequence alignment through sequence weighting, position-specific gap penalties and weight matrix choice. Nucleic Acids Res 22, 4673-4680.

Tvrzová, L., Schumann, P., Spröer, C., Sedláček, I., Páčová, Z., Šedo, O., Zdráhal, Z., Steffen, M. \& Lang, E. (2006). Pseudomonas moraviensis sp. nov. and Pseudomonas vranovensis sp. nov., soil bacteria isolated on nitroaromatic compounds, and emended description of Pseudomonas asplenii. Int J Syst Evol Microbiol 56, 2657-2663.

Verhille, S., Baïda, N., Dabboussi, F., Hamze, M., Izard, D. \& Leclerc, H. (1999). Pseudomonas gessardii sp. nov. and Pseudomonas migulae sp. nov., two new species isolated from natural mineral waters. Int J Syst Evol Microbiol 49, 1559-1572.

Yi, H., Chang, Y.-H., Oh, H. W., Bae, K. S. \& Chun, J. (2003). Zooshikella ganghwensis gen. nov., sp. nov., isolated from tidal flat sediments. Int J Syst Evol Microbiol 53, 1013-1018.

Yoon, J. H., Kim, I. G., Shin, D. Y., Kang, K. H. \& Park, Y. H. (2003a). Microbulbifer salipaludis sp. nov., a moderate halophile isolated from a Korean salt marsh. Int J Syst Evol Microbiol 53, 53-57.

Yoon, J. H., Shin, D. Y., Kim, I. G., Kang, K. H. \& Park, Y. H. (2003b). Marinobacter litoralis sp. nov., a moderately halophilic bacterium isolated from sea water from the East Sea in Korea. Int J Syst Evol Microbiol 53, 563-568.

Yoon, J. H., Kim, I. G., Oh, T. K. \& Park, Y. H. (2004). Microbulbifer maritimus sp. nov., isolated from an intertidal sediment from the Yellow Sea, Korea. Int J Syst Evol Microbiol 54, 1111-1116. 